\title{
Implementasi program aplikasi rekapitulasi pembayaran SPP pada SMK Prima Tiara Makassar
}

\author{
Mashud $^{1 *}$, Rohayati ${ }^{1}$, First Wanita ${ }^{2}$, Erwin Gatot ${ }^{2}$, \\ Ibnu Taimiyah Darwis ${ }^{2}$, Paramita ${ }^{2}$ \\ 1 Sistem Informasi, STMIK AKBA \\ 2 Teknik Infromatika, STMIK AKBA \\ mashud@akba.ac.id
}

\begin{abstract}
This community service program aims to design and implement the SPP payment application at SMK Prima Tiara Makassar. The problem arises when the treasurer collects data on students who have paid and who have not paid tuition, this causes a lot of time to be wasted. In addition, the payment record book will become damaged so that the reporting of monthly payments will be late. So that the existence of a payment application helps in the payment process for SPP SMK Prima Tiara Makassar.
\end{abstract}

Keywords: Application; Payment; SPP; School; Makassar

\begin{abstract}
Abstrak
Program pengabdian kepada masyarakat ini bertujuan untuk merancang dan mengimplementasikan aplikasi pembayaran SPP pada SMK Prima Tiara Makassar. Permasalahan muncul ketika bendahara melakukan rekapan data siswa yang sudah membayar dan yang belum membayar SPP, hal ini menyebabkan banyaknya waktu yang terbuang. Selain itu, buku catatan pembayaran akan menjadi rusak sehingga pelaporan pembayaran perbulan menjadi terlambat. Sehingga dengan adanya aplikasi pembayaran membantu dalam proses pembayaran SPP SMK Prima Tiara Makassar.
\end{abstract}

Kata Kunci: Aplikasi; Pembayaran; SPP; Sekolah; Makassar

\section{PENDAHULUAN}

Perkembangan teknologi dan perkembangan ilmu pengetahuan memicu banyak kalangan untuk mencari alternatif pemecahan masalah di bidang teknologi sistem informasi. Teknologi informasi saat ini merupakan kebutuhan yang sangat penting bagi organisasi dan perusahaan. Teknologi informasi telah banyak digunakan untuk berbagai aspek seperti manajemen dan sumber daya manusia. Salah satu contoh teknologi informasi yang digunakan dalam aspek manajemen yaitu proses administrasi pembayaran SPP.

Dengan bantuan teknologi dapat membantu meningkatkan kualitas dan kinerja sekolah. Menggunakan teknologi dapat dengan cepat menyederhanakan pekerjaan tanpa redundansi yang tidak perlu. Selain meningkatkan mutu sekolah, perlu juga digunakan 
teknologi pendukung, seperti penggunaan aplikasi pembayaran SPP sekolah, agar proses pencatatan dan pembayaran dapat dilakukan secara efektif, efisien dan mudah. Di era modern ini, Pada tingkat pendidikan Sekolah Menengah Kejuruan (SMK), belum banyak sekolah yang mengenal dan memanfaatkannya dengan baik teknologi ini untuk membantu peningkatan mutu sekolah (Rochman, 2018). Oleh karena itu, untuk mendukung peningkatan kualitas sekolah, perlu dilakukan penggantian sistem yang tidak menggunakan teknologi, seperti masih menggunakan aplikasi pembayaran SPP yang tercatat secara manual di buku, dan lain sebagainya.

Pada penelitian sebelumnya permasalahan yang dihadapi sekolah adalah belum adanya sistem pemrosesan pembayaran SPP yang efektif dan efisien, yang dapat diatasi dengan sistem berbasis desktop (Desy Christina Sihombing, 2012). Oleh karena itu, proses pengelolaan secara manual untuk membayar banyak pembayaran SPP tentunya akan memakan waktu yang lama sehingga dapat mengakibatkan pengelolaan keuangan yang tidak memuaskan. Untuk mewujudkan laporan keuangan yang baik diperlukan pengelolaan keuangan yang baik. Manajemen berdampak pada efektivitas dan efisiensi realisasi rencana kerja . Proses pendataan dan pengelolaan keuangan siswa memegang peranan yang sangat penting.Hal ini penting untuk pembayaran Dana Donasi Pembangunan (DSP) dan pembayaran SPP bulanan siswa. Informasi ini sangat berpengaruh untuk kelancaran proses pembelajaran. dan memaksimalkan penggunaan fasilitas sekolah (Erinawati, 2014).

SMK Prima Tiara Makassar merupakan institusi yang bergerak dalam bidang pendidikan. Sekolah membutuhkan suatu pengelolahan administrasi dengan menyediakan data-data guna untuk melakukan proses pencatatan pembayaran SPP sekolah. Pencatatan pembayaran memiliki peran penting dalam menunjang kegiatan pembelajaran dan operasional sekolah, sehingga tertatanya pencatatan menjadi poin kunci untuk keberlangsungan pembayaran.

Proses pengelolahan pencatatan pembayaran SPP membutuhkan tingkat ketelitian dalam prosesnya, hal ini berkaitan mengenai pelaporan keuangan perbulan, pelaporan lunas iuran dan pelaporan tunggakan perbulan yang dilaporkan ke kepala sekolah dan komite sekolah. Proses pencatatan pembayaran SPP dilakukan secara mandirioleh siswa yang dimulai dari siswa mendatangi loket pembayaran, selanjutnya memberikan kartu pembayaran SPP beserta uang pembayaran yang kemudian akan dicatat oleh pihak bendahara sekolah di dalam buku pembayaran SPP dan kartu pembayaran.

Permasalahan muncul ketika bendahara melakukan rekapan data siswa yang sudah membayar dan yang belum membayar SPP, hal ini menyebabkan banyaknya waktu yang terbuang. Selain itu, buku catatan pembayaran akan menjadi rusak sehingga pelaporan pembayaran perbulan menjadi terlambat. Berdasarkan permasalahan yang dipaparkan, maka dibuat aplikasi pengelolahan pencatatan pembayaran SPP sebagai salah satu segi layanan yang digunakan untuk menunjang kegiatan kebendaharaan dengan adanya pengelolahan pencatatan pembayaran SPP, pencatatan dan pelaporan dapat 
diproses dengan cepat dan tepat.

\section{METODE PELAKSANAAN}

\subsection{Tahapan Pengumpulan Data}

Adapun teknik pengumpulann data penulis dalam menyelesaikan penelitian ini dengan cara sebagai berikut :

1) Studi Kepustakaan .

Studi kepustakaan merupakan salah satu teknik pengumpulan data dengan mencari teori-teori yang telah dikembangkan dalam bidang ilmu yang berhubungan dengan pembuatan aplikasi serta melakukan referensi dengan buku-buku yang berkaitan dengan masalah yang penulis angkat.

2) StudiWawancara.

Studi wawancara adalah salah satu teknik pengumpulan data dengan cara wawancara (interview) guna mengumpulkan data-data yang diperlukan.

3) Eksplorasi Internet.

Eksplorasi Internet adalah melakukan penelusuran situs-situs internet yang berhubungan dengan tema yang diangkat dalam penyusunan penelitian ini.

2.2 Tahapan - Tahapan Pelaksanaan

1) Tahap persiapan

Pada tahap persiapan dan pengenalan ini, tim Pengabdian Masyarakat akan melakukan survei tempat untuk melihat kondisi sekolah dan mengidentifikasi permasalahan dalam proses operasional pendidkan yang kemungkinan dapat diselesaikan dengan memanfaakan teknolgi informasi.

2) 2. Tahap Pelaksanaan kegiatan

Setelah bentuk kegiatan berhasil diidentifikasi, maka akan dilakukan pelaksanaan kegiatan yang terdiri dari tiga aktifitas utama, yakni penggalian kebutuhan sistem, pembuatan, dan penerapan. Kebutuan sistem digali melalui wawancara, evaluasi dokumen, dan pemberian contoh bentuk sistem. Selanjutnya pada aktivitas pembuatan, dimulai dengan perancangan alur sistem. Penerapan sistem baru dimulai dengan sosialisasi.

3) Tahap Evaluasi

Setelah sistem selesai dibangun, maka tahap selanjutnya adalah evaluasi.

2.3 Tempat, Waktu dan Susunan Acara

1) Waktu dan lokasi Kegiatan

Berikut waktu dan lokasi kegiatan pengabdian kepada masyarakat di SMK PRIMA TIARA MAKASSAR:

Hari/ Tanggal $\quad$ : Rabu, 16 Januari 2019

Waktu : $09.00-12.30$ WITA

Alamat : Jl. Tamalanrea Raya D No.5, Tamalanrea, Kec. Tamalanrea, Kota Makassar, Sulawesi Selatan 
2) Susunan Acara kegiatan pengabdian kepada masyarakat di SMK Prima Tiara Makassar:
a. Pembukaan
b. Kata Sambutan Ketua P3M STMIK AKBA
c. Penyampaian Materi tentang Aplikasi Rekapitulasi Pembayaran SPP Pada SMK Prima Tiara Makassar
d. Diskusi dan Tanya Jawab
e. Penutup

\section{HASIL DAN PEMBAHASAN}

\subsection{Pelaksanaan Kegiatan}

Kegiatan pengabdian masyarakat pada SMK Prima Tiara Makassar diawali dengan pembukaan dilanjutkan sambutan oleh Ketua P3M STMIK AKBA Ibu Dra. Ratnawati, M.Si.

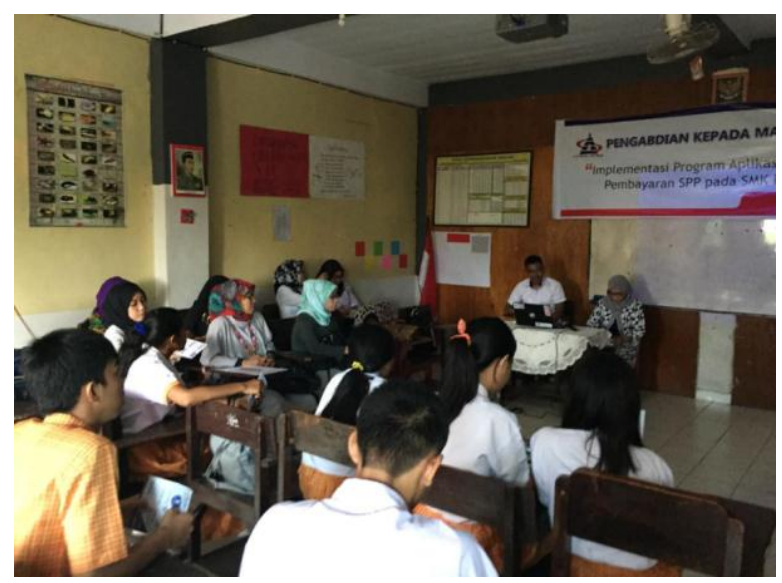

Gambar 1. Pembukaan dan Sambutan Ketua P3M

Setelah pembukaan dan sambutan dilanjutkan penyampaian materi tentang Aplikasi Rekapitulasi Pembayaran SPP Pada SMK Prima Tiara Makassar.

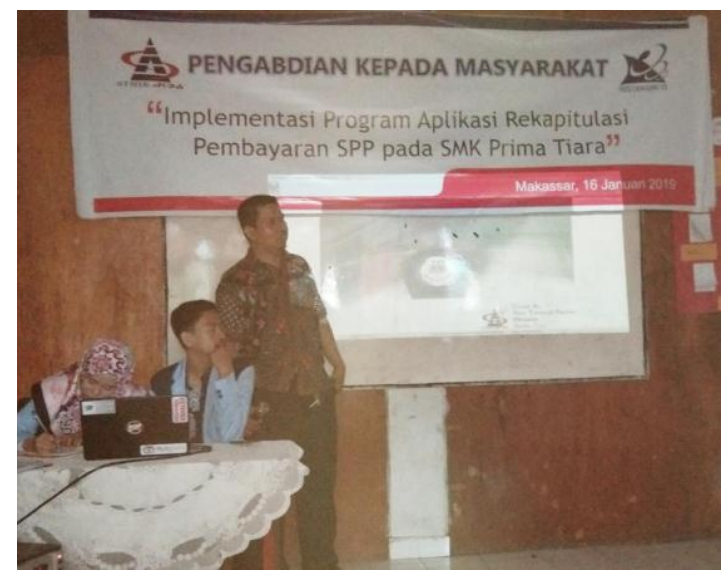

Gambar 2. Penyampaian Materi 
Aplikasi pembayaran SPP sudah berhasil dibuat dan install. Langkah awal untuk mengunakan aplikasi ini terlebih dahulu pengguna harus login. Gambar 3. menunjukkan tampilan login aplikasi.

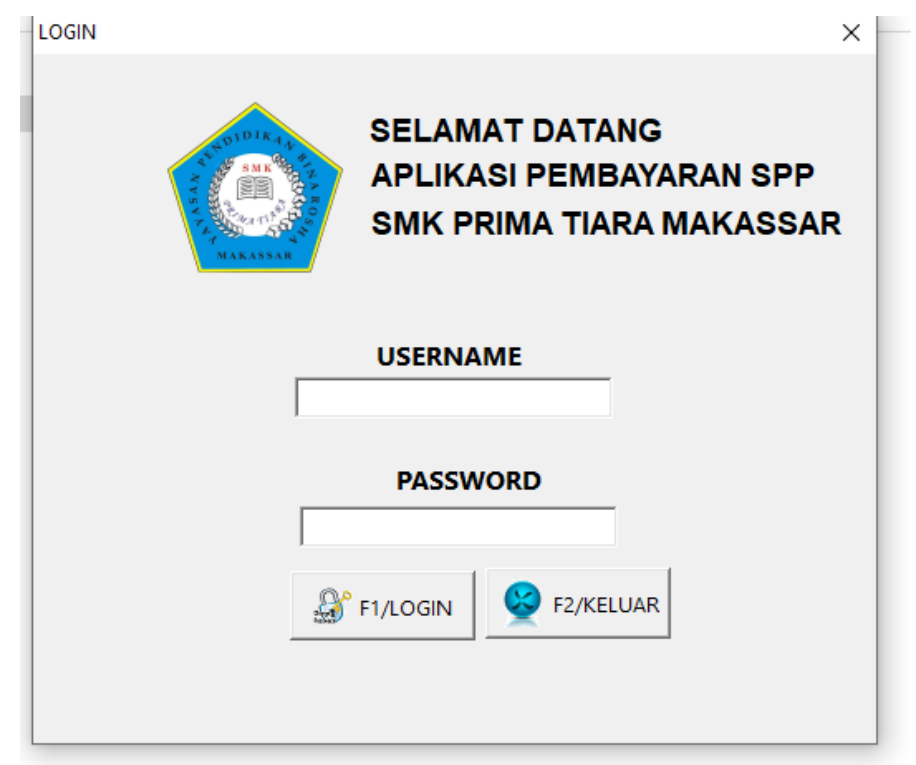

Gambar 3. Tampilan login Aplikasi

Salah satu menu yang ada dalam aplikasi pembayaran SPP yaitu cetak kartu. Gambar 4. menunjukkan tampilan form cetak kartu.

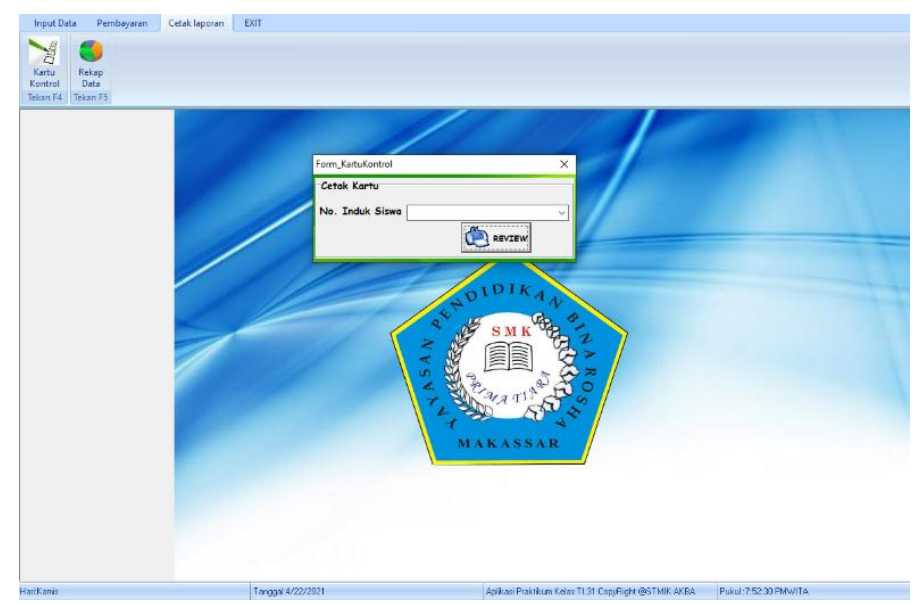

Gambar 4. Tampilan Form Cetak Kartu

Setelah memasukkan No Induk Siswa dan Klik tombol Preview. Gambar 4. menunjukkan tampilan form cetak kartu 


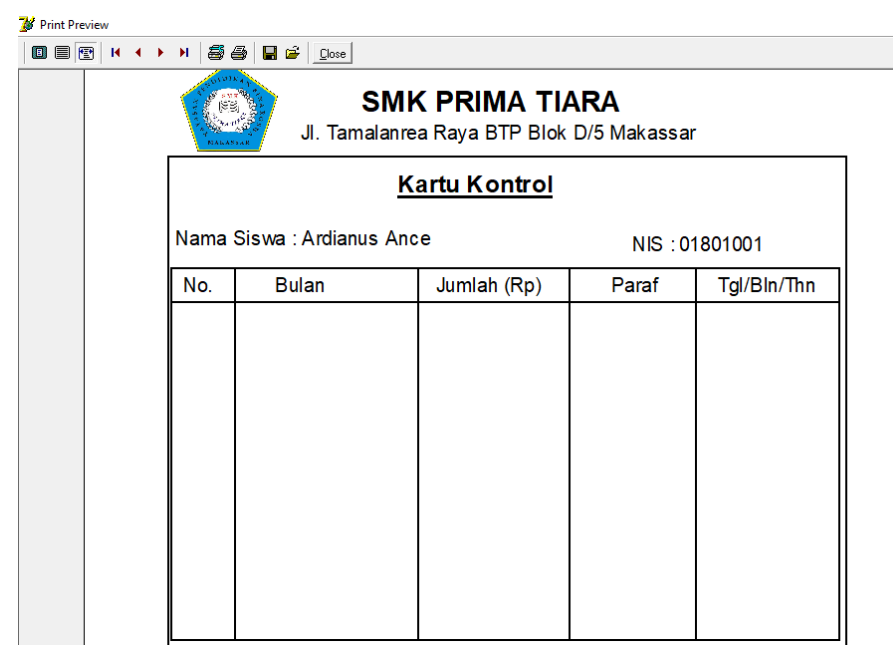

Gambar 5. Tampilan Kartu Kontrol

Setelah selesai pemaparan materi dilanjutkan dengan diskusi. Dan ditutup dan photo bersama.

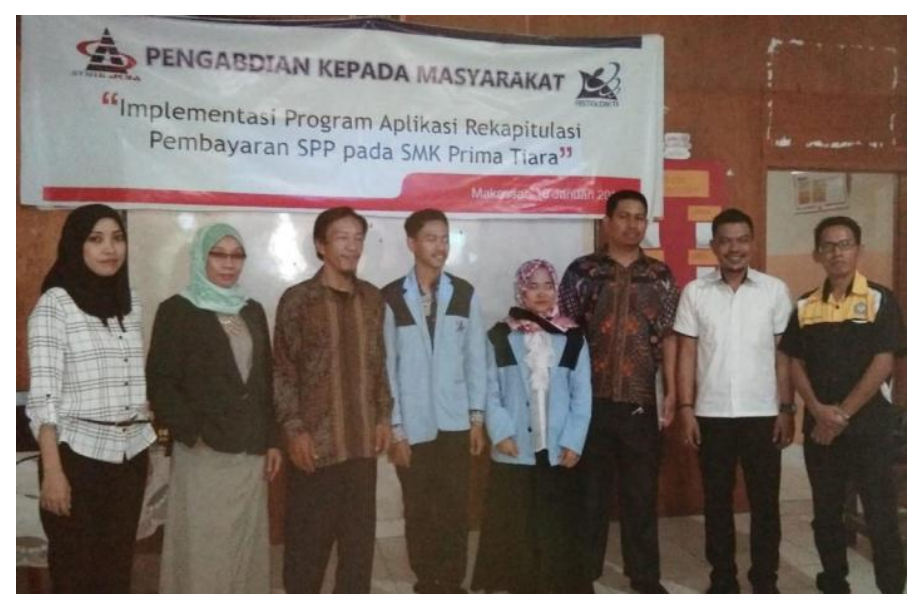

Gambar 6. Photo Bersama

Hasil yang dicapai dengan diadakannya kegiatan pengabdian kepada masyarakat di SMK Prima Tiara Makassar yaitu siswa, guru, dan dosen dapat mengetahui Aplikasi Rekapitulasi Pembayaran SPP sehingga memudahkan pihak sekolah khususnya siswa dan guru dalam menjalankan proses pembayaran SPP.

\subsection{Evaluasi hasil kegiatan}

Berikut adalah evaluasi hasil kegiatan meliputi situasi pelaksanaan, analisa kelebihan, kekurangan, hambatan, peluang pengembangan, pelajaran apa yang dapat diambil dari hasil evaluasi.

1) Situasi Pelaksanaan

Situasi pelaksanaan kegiatan pengabdian kepada masyarakat di SMK Prima Tiara Makassar dengan judul Aplikasi Rekapitulasi Pembayaran SPP berjalan baik, peserta menyimak materi dan aktif dalam sesi tanya jawab dan diskusi.

2) Kelebihan yang ditemukan saat pelaksanaan : 
Kelebihan yang ditemukan saat kegiatan yaitu peserta diberi kesempatan untuk memberikan saran serta perbaikan yang dapat dilakukan untuk aplikasi yang ditawarkan.

3) Kekurangan yang ditemukan saat pelaksanaan kegiatan :

Kekurangan yang dtemukan adalah saat peserta mengajukan pertanyaan waktu yang disediakan kurang untuk memenuhi semua pertanyaan.

4) Peluang pengembangan :

Peluang pengembangan kegiatan pengabdian kepada masyarakat di SMK Prima Tiara Makassar dengan judul Aplikasi Rekapitulasi Pembayaran SPP sangat besar dan berpengaruh pada kerjasama antar STMIK AKBA dan SMK Prima Tiara Makassar kedepan.

\section{SIMPULAN}

Kesimpulan yang dapat diambil dalam pelaksaan kegiatan pengabdian kepada masyarakat di SMK Prima Tiara Makassar dengan tema Implementasi Aplikasi Rekapitulasi Pembayaran SPP yaitu membantu dalam proses pembayaran SPP SMK Prima Tiara Makassar.

\section{UCAPAN TERIMA KASIH}

Pelaksana pengabdian masyarakat mengucapkan terima kasih kepada P3M STMIK AKBA atas bantuan dana dan motivasi dalam melaksanakan pengabdian dan kepada Pihak Sekolah SMK Prima Tiara yang telah bersedia menjadi mitra dalam pengabdian masyarakat ini.

\section{REKOMENDASI}

Berdasarkan evaluasi dan monitoring yang dilakukan maka rekomendasi yang kami ajukan bagi kegiatan ini adalah kegiatan serupa seharusnya dilaksanakan secara kontinyu dengan tema yang berbeda dalam pemgembangan teknologi di SMK Prima Tiara Makassar.

\section{REFERENSI}

Agustinus, J. (2014). Pengelolaan Keuangan yang Efektif dan Efisien dalam Meningkatkan Kekuatan Ekonomi bagi Masyarakat Papua dan Papua Barat di Indonesia. Jurnal Aplikasi Manajemen, 1-9.

Desy Christina Sihombing, E. (2012). Perancangan dan Implementasi Sistem Informasi Administrasi Pembayaran SPP di SMP Negeri 1 Salatiga Menggunakan Metode Prototype.

Erinawati, H. D. (2014). Pembangunan Sistem Informasi Pembayaran Sekolah Pada Sekolah Menegah Atas (SMA) Negeri 1 Rembang Berbasis Web. . Speed-Sentra Penelitian Engineering dan Edukasi, 40-46.

Rochman, A. (2018). Perancangan Sistem Informasi Administrasi Pembayaran SPP Siswa Berbasis Web di SMK Al Amanah. JURNAL SISFOTEK GLOBAL, 51-56. 